\title{
Analisis Sistem Just In Time Meningkatkan Produktivitas (Studi Kasus Usaha Batu Tela Beton Mas)
}

\author{
Irsyad Hardinansah, Dirarini Sudarwadi ${ }^{1}$, Nurwidianto ${ }^{1}$ \\ ${ }^{1}$ Jurusan Manajemen Universitas Papua
}

Received: Februari 2020; Accepted: Maret 2020; Published: Maret 2020

\begin{abstract}
Abstrak
Penelitian ini bertujuan untuk mengetahui penerapan sistem Just In Time pada Usaha Batu Tela Beton Mas dalam usaha untuk meningkatkan produktivitas. Penelitian ini menggunakan data primer dan data sekunder dengan teknik pengumpulan data menggunakan interview, observasi dan dokumentasi. Hasil penelitian menunjukkan bahwa dengan menggunakan sistem Just In Time pada sistem pembelian dan sistem produksi, dapat meningkatkan produktivitas perusahaan. Hal ini terbukti kebenarannya bahwa dengan penerapan sistem pembelian Just In Time dapat menekan biaya penyimpanan. Penerapan sistem Just In Time Purchasing secara langsung dapat memberikan dampak yang besar terhadap efisiensi biaya dan produktivitas. Penerapan sistem Just In Time Production mampu menekan aktivitas yang tidak menambah nilai (non value added) atau meningkatkan manufacturing cycle efficiency. Meningkatnya MCE disebabkan semakin kecilnya aktivitas yang tidak menambah nilai (non value added) pada proses produksi. Dengan meningkatnya MCE akibat hilangnya aktivitas yang tidak menambah nilai. maka penerapan sistem Just In Time Production mampu meningkatkan produktivitas perusahaan. Implikasi dari hasil penelitian ini adalah memberikan saran kepada perusahaan agar sebaiknya perusahaan menerapkan sistem Just In Time dalam pengelolaan perusahaan sehingga dapat meningkatkan produktivitas perusahaan.
\end{abstract}

Kata kunci: Just In Time, biaya penyimpanan, produktivitas perusahaan

\begin{abstract}
This study aims to determine the application of the Just In Time system at the Batu Tela Beton Mas Business in an effort to increase company productivity. This study uses primary data and secondary data with data collection techniques using interviews, observation and documentation. The results of the study show that using the Just In Time system on the purchasing system and production system can increase the productivity of the company. This is proven to be true that the implementation of the Just In Time purchasing system can reduce storage costs. Implementation of the Just In Time Purchasing system can directly have a large impact on cost efficiency and productivity. The application of the Just In Time Production system is able to suppress activities that do not add value (non value added) or improve manufacturing cycle efficiency. The increase in MCE is caused by the smaller activities that do not add value (non value added) to the production process. With increasing MCE due to loss of activity that does not add value. then the application of the Just In Time Production system can increase company productivity. The implication of the results of this study is to give advice to companies so that companies should implement the Just In Time system in managing the company so that it can increase the productivity of the company
\end{abstract}

Keywords: Just In Time, storage costs, company productivity

How to Cite:Hardinansah, I., Sudarwadi, D., Nurwidianto (2020). Analsis Sistem Just In Time Dalam Meningkatkan Produktivitas (Studi Kasus Usaha Batu Tela Beton Mas. JFRES: Journal of Fiscal and Regional Economy Studies, 3(1), 56 - 65

Corresponding author:
E-mail: dirarini@gmail.com

Journal of Fiscal and Regional Economy Studies 


\section{PENDAHULUAN}

Saat ini, banyak terjadi perubahan yang cukup drastis pada lingkungan bisnis dunia secara global. Hansen dan Mowen (2001) menyatakan bahwa terjadinya perubahan di dalam lingkungan bisnis mencakup: Persaingan ekonomi yang semakin bersifat global telah memicu terjadinya persaingan bisnis yang semakin ketat antar perusahaan, pelanggan menuntut kualitas produk serta harga yang murah terhadap produk-produk yang dihasilkan oleh perusahaan, dan waktu menjadi salah satu unsur persaingan di dalam lingkungan bisnis. Meylianti dan Mulia (2009) menyatakan persaingan yang sangat ketat antar perusahaan memaksa perusahaan untuk menjadi paling baik dari yang terbaik untuk dapat bertahan di era globalisasi ini. Salah satu cara yang dapat ditempuh oleh perusahaan untuk dapat menjadi yang terbaik adalah dengan memiliki corporate strategy yang baik sehingga dapat memeroleh keunggulan bersaing.

Di dalam lingkungan bisnis tersebut akhirnya memicu setiap perusahaan untuk memikirkan kembali upaya - upaya atau usaha lain yang dirasa akan dapat meningkatkan produktivitas (finansial atau modal, tenaga kerja, produk, organisasi, penjualan, dan produksi), efisiensi, kualitas, efektivitas, ketepatan waktu, dan pemberian pelayanan yang diharapkan dapat meningkatkan keunggulan kompetitif (advantage competitive) perusahaan sehingga dapat bertahan dan mampu untuk bersaing pada pasar global. (Diaz dan Retnani, 2015).

Perusahaan hidup dalam lingkungan yang berubah cepat, dinamik, dan rumit. Perubahan tersebut tidak hanya bersifat evolusioner namun seringkali sifatnya revolusioner. Dari segi bisnis, lingkungan adalah pola semua kondisi atau faktor eksternal yang mempengaruhi kehidupan dan pengembangan perusahaan. Lingkungan tersebut meliputi ekonomi politik dan kebijaksanaan pemerintah, pasar dan persaingan, pemasok sosial dan budaya serta teknologi. Perkembangan yang pesat dalam sektor industri dewasa ini mengakibatkan semakin banyaknya tingkat persaingan yang dihadapi tiap-tiap perusahaan dalam mencapai tujuan perusahaan. Untuk dapat bersaing dalam merebut pasar tiap perusahaan akan berusaha untuk saling mengungguli, hal ini diupayakan untuk meraih keuntungan yang sebesar-besarnya (Diaz dan Retnani, 2015).
Heizer dan Render (2005), mengatakan bahwa dalam membangun Competitive advantage atau biasa dikenal dengan keunggulan bersaing, perusahaan disarankan untuk membentuk sebuah sistem unik dan memiliki keunggulan dibanding pesaing. Intinya adalah memberikan nilai terbaik bagi konsumen dengan efisien dan dapat dipertahankan. Nilai yang baik di mata konsumen adalah ketika perusahaan dapat memenuhi kebutuhan konsumen sesuai dengan yang diharapkan.

Wardhani (2015) dalam Pratama 2018, dalam perkembangan ekonomi dewasa ini, dimana dunia usaha tumbuh dengan pesat di Indonesia. Pengusaha dituntut untuk bekerja dengan lebih efisien dalam menghadapi persaingan yang lebih ketat demi menjaga kelangsungan operasi perusahaan. Untuk menghadapi persaingan tersebut, dunia industri Indonesia harus siap dan kompetitif, oleh karena itu usaha-usaha dalam perencanaan, pelaksanaan, pengorganisasian dan pengendalian dalam perusahaan perlu ditingkatkan agar dapat mencapai tujuan perusahaan serta meningkatkan daya saingnya.

Handoko (2016) dalam Pratama 2018, menyatakan, telah banyak dikatakan bahwa tujuan umum perusahaan (bisnis) adalah "membuat suatu produk atau jasa dengan biaya yang serendah-rendahnya, menjual dengan harga wajar, dan membentuk kebiasaan “. Bila kita menganalisa pernyataan ini, kita mendapatkan dua fungsi esensial setiap perusahaan-produksi dan pemasaran. Fungsi seleksi "pembentukan kebiasaan" dan penentuan harga. Sedangkan produksi berurusan dengan sisi penawaran (supply side) - misal, penciptaan produk dengan seminimal mungkin - dari seluruh tipe organisasi, baik manufacturing (pabrikasi), jasa, perusahaan swasta, perusahaan negara, bermotif keuntungan maupun non-keuntungan.

Di Indonesia dengan kondisi perekonomian yang tidak stabil akibat krisis moneter tahun 1998, tingkat inflasi yang tinggi, dan adanya perdagangan bebas di kawasan Asia; mengakibatkan persaingan di dalam negeri dan di dunia Internasional semakin ketat. Keadaan ini juga semakin mendorong dipertanyakannya kemampuan bersaing perusahaan dalam mempertahankan kelangsungan hidup masingmasing perusahaan di tengah situasi sosial yang seperti sekarang ini. Suatu perusahaan yang mempunyai kemampuan bersaing adalah suatu perusahaan yang dapat menjalankan operasi 
perusahaan secara efisien dan efektif, sehingga pemborosan-pemborosan sumber daya dapat dihindari. (Ningrum, 2010).

Lingkungan manufaktur bagi perusahaanperusahaan tradisional yang memiliki batch besar dan biaya persiapan yang tinggi telah berubah secara dramatis dalam 10 hingga 20 tahun terakhir, dalam satu hal, pasar kompetititf tidak lagi ditentukan oleh batasan Negara. Kemajuan dalam transportasi dan komunikasi telah banyak berperan dalam menciptakan kompetisi global. Kemajuan teknologi telah menyebabkan siklus hidup produk menjadi lebih singkat dan keragamanan produk semakin meningkat. Perusahaan asing menawarkan produk berkualitas lebih tinggi dan berharga lebih rendah dengan fitur khusus sehingga menciptakan tekanan berat pada perusahan domestic yang memiliki batch besar dan biaya persiapan tinggi untuk meningkatkan kualitas dan keanekaragaman produk sambil mengurangi total biaya secara simultan. Tekanan persaingan ini menyebabkan perusahaan harus meiliki strategi yang ampuh untuk bersaing. (Hensen dan Mowen, 2013).

Salah satu upaya yang dapat ditempuh oleh perusahaan untuk dapat memeroleh keunggulan bersaing adalah dengan meningkatkan produktivitas perusahaan (finansial atau modal, tenaga kerja, produk, penjualan, produksi, efesiensi ketepatan waktu). Karena bagi perusahaan produktivitas sangatlah penting, yaitu menghasilkan barang yang lebih baik dengan biaya per unit yang lebih rendah. Hal ini akan meningkatkan daya saing perusahaan, karena dengan peningkatan produktivitas perusahaan, perusahaan akan memperoleh keuntungan. (Zulian Yamit, 2005: dalam Adiko, 2010).

Salah satu strategi yang dapat digunakan untuk meningkatkan produktivitas perusahaan adalah dengan sistem Just In Time. Sistem yang dapat meningkatkan produktivitas perusahaan dengan cara mengeliminasi segala bentuk pemborosan. Sistem ini berfokus pada usaha-usaha mengeliminasi segala bentuk pemborosan (waste) yang tidak bernilai tambah dan meningkatkan aktivitas yang bernilai tambah.

Just In Time dikenal sebagai filosofi yang berfokus pada usaha-usaha untuk mengeliminasi segala bentuk pemborosan yang berupa aktivitas yang tidak bernilai tambah (non value-added activity) dan meningkatkan aktivitas yang bernilai tambah (value added activity). Dengan menerapkan strategi ini, perusahaan dapat menekan pemborosan yang terjadi khususnya dalam pengelolaan persediaan. (Agustina, dkk., 2007).

Just In Time menganggap kelebihan persediaan sebagai pemborosan. Namun, mengurangi persediaan bukanlah tujuan utama dari Just In Time. Herry, (2011). Tujuan Just In Time adalah untuk meningkatkan produktivitas dengan cara mengurangi berbagai aktivitas yang tidak memberikan nilai tambah bagi produk. Peningkatan produktivitas merupakan motor penggerak kemajuan ekonomi dan keuntungan perusahaan. Produktivitas juga penting untuk meningkatkan upah dan penerimaan perseorangan. (Schroeder, 1994).

Just-In-Time juga mengharuskan perusahaan meningkatkan kualitas barang yang diproduksi, misalnya perusahaan juga harus memperhatikan jenis dan mutu dari material yang digunakan dalam proses produksi, mutu peralatan, dan mutu. Sistem Just In Time menitikberatkan pada pembelian persediaan dalam jumlah yang tepat, waktu yang tepat dan pada tempat yang tepat. Pada sistem ini ciri yang utama adalah tidak adanya persediaan karena persediaan dianggap hanya merupakan pemborosan. Dalam sistem produksi Just In Time, persediaan dibeli sangat kecil dengan pengiriman berkala dan tepat waktu saat digunakan. Tujuan utama Just In Time adalah menghilangkan pemborosan dan konsisten dalam meningkatkan produktivitas (Putra dan Idayati, 2014).

Sasaran utama Just In Time adalah meningkatkan produktivitas sistem produksi atau operasi dengan cara menghilangkan semua macam kegiatan yang tidak menambah nilai (pemborosan) bagi suatu produk. Sasaran Just In Time menitik beratkan pada perbaikan berkesinambungan (continuos improvement) untuk mencapai biaya produksi yang rendah, tingkat produktivitas yang lebih tinggi, kualitas dan reliabilitas produk yang lebih baik, memperbaiki waktu penyerahan produk akhir dan memperbaiki hubungan kerja antara pelanggan dengan pemasok. (Diaz dan Retnani, 2015).

Hensen dan Mowen (2013) mengemukakan bahwa terdapat dua macam Just In Time yakni Just In Time Manufacturing dan Just In Time purchasing, sedangkan menurut Agustina, dkk., (2007) secara garis besar Just In Time terdiri Journal of Fiscal and Regional Economy Studies 
dari Just In time Purchasing dan Just In Time Production. Dimana, menurut Putra dan Idayati (2014) Just In Time Purchasing adalah sistem pembelian penjadwalan pengadaan barang atau bahan yang tepat waktu sehingga dapat dilakukan pengiriman atau penyerahan secara cepat dan tepat untuk memenuhi permintaan. Selanjutnya, Supriyono (2002) mengatakan bahwa Just In Time Production adalah sistem penjadwalan produksi komponen atau produk yang tepat waktu, mutu, dan jumlahnya sesuai dengan yang diperlukan oleh tahap produksi berikutnya atau sesuai dengan memenuhi permintaan pelanggan.

\section{METODE PENELITIAN}

Jenis penelitian ini adalah studi kasus, dengan metode pendekatan kuantitatif deskriptif. Arikunto (2006) mengungkapkan bahwa penelitian kasus adalah suatu penelitian yang dilakukan secara terperinci dan mendalam terhadap suatu organisasi, lembaga atau gejala tertentu. Tujuan dari penelitian studi kasus yaitu untuk mencari solusi pemecahan permasalahan yang terjadi dengan mendiskripsikan gambaran permasalahan yang terjadi secara sistematis berdasarkan fakta-fakta yang aktual, dan mengetahui sifat atau hubungan variabel yang diteliti kemudian dilakukan analisis agar dapat diperoleh sebuah kesimpulan sebagai solusi pemecahan permasalahan.

Untuk menganalisis dan menginterpretasikan data dengan baik, maka diperlukan data yang akurat dan sistematis agar hasil yang didapat mampu mendeskripsikan situasi objek yang sedang diteliti dengan benar. Dalam tahap pengumpulan data. Yaitu dengan melakukan wawancara, observasi, dan studi dokumentasi.

Kegunaan dari analisis data adalah untuk mengolah data sedemikian rupa, sehingga berhasil dikumpulkan kebenaran-kebenaran yang dapat dipakai untuk menjawab persoalanpersoalan yang diajukan dalam penelitian. (Diaz dan Retnani, 2015). Analisis dilakukan dengan cara membandingkan antara teori-teori yang diperoleh dari hasil studi kepustakaan dengan data-data yang diperoleh saat survey dan studi lapangan.

\section{Perhitungan Sistem Just In Time Production}

Penerapan sistem produksi sangatlah diperlukan oleh perusahaan, sebab dengan perhitungan sistem produksi yang akurat maka efektivitas dalam pengelolaan produksi akan terlaksana sesuai dengan yang diharapkan. Oleh karena itu, dalam sistem produksi perusahaan perlu memerlukan waktu aktivitas produk yang digunakan dalam proses produksi.

Lamanya waktu yang dibutuhkan untuk menyelesaikan suatu produk dalam produksi secara keseluruhan disebut throughput time. (Tjiptono dan Anastasia 2003). Throughtput time ini terdiri dari value added (processing) time dan non value added time. Troughput time dapat ditentukan dengan menggunakan rumus:

Troughput Time $=$ Processing Time $(V A A)+$ Inspeksi Time + Waiting Time + Move Time (NVAA)

Just In Time Production dapat mengurangi bahkan menghilangkan inspection time, waiting time, moving time sehingga dapat meningkatkan produktivitas akibat hilangnya aktivitas tidak bernilai tambah. (Agustina, dkk, 2007). Untuk meningkatkan produktivitas perusahaan dengan cara menghilangkan aktivitas tidak bernilai tambah dalam sistem Just In Time, maka produktivitas perusahaan diukur dengan menggunakan model Manufacturing Cycle Efficiency (MCE). (Saputra Novan, dkk, 2015) dan (Agustina, dkk, 2007). Model ini merupakan metode pengukuran fisik dari produktivitas perusahaan. dimana MCE yang ideal dicapai jika sama dengan 1 atau mendekati angka 1, yang berarti perusahaan dapat menghilangkan waktu dari aktivitas yang tidak bernilai tambah (nonvalue added activities) dan mengoptimalkan waktu dari aktivitas yang bernilai tambah (value added activities). (Saputra Novan, dkk, 2015)

Manufacturing Cycle Efficiency (MCE) ini dapat diterapkan pada proses produksi secara spesifik (khusus) maupun secara keseluruhan. MCE dapat diukur melalui persamaan dibawah ini:

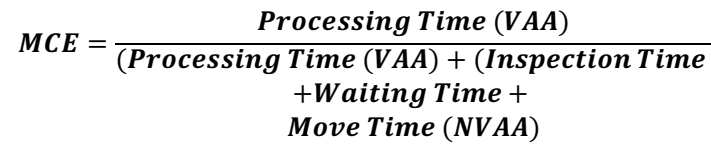

Berkaitan dengan dua rumus di atas, maka hal ini perlu diterapkan pada aktivitas produksi campuran batu tela pada Beton Mas agar dalam melakukan produksi beton perusahaan dapat mengurangi atau menghilangkan waktu inspeksi (inspection time), waktu menunggu (waiting time) dan waktu memindahkan (moving time) atau dapat menghilangkan aktivitas tidak bernilai tambah. Sehingga dapat meningkatkan produktivitas akibat hilangnya aktivitas tidak bernilai tambah. 


\section{HASIL PENELITIAN}

\section{Sistem Just In Time Purchasing}

Menurut Adiko (2010) Just In Time Purchasing adalah sistem pembelian barang dengan jumlah dan waktu yang tepat sehingga barang tersebut dapat segera diterima untuk memenuhi permintaan atau untuk digunakan. Just In Time Purchasing dibutuhkan karena mensyaratkan para pemasok untuk mengirimkan bahan baku tepat pada waktunya dan dalam jumlah yang tepat pula untuk diproduksi.

Just In Time Purchasing dapat menghasilkan efisiensi biaya yang menciptakan produktivitas perusahaan. Perusahaan manufaktur yang membeli bahan baku sesuai dengan yang dibutuhkan dari pemasok dengan tepat waktu dapat meminimalkan biaya pemborosan. (Adiko, 2010). Dengan meminimalkan biaya pemborosan (biaya penyimpanan) maka akan meningkatkan produktivitas perusahaan.

Berkenaan dengan uraian di atas, maka dalam penelitian ini, peneliti akan menganalisis besarnya produksi batu tela yang dipoduksi oleh perusahaan dan Just In Time. Lalu kemudian membandingkan besarnya produksi batu tela sebelum dan sesudah penerapan sistem Just In Time.

\section{Data Persediaan Produk batu Tela Sebelum Penerapan Just In Time}

Pada usaha beton mas masih menggunakan sistem tradisional dimana mereka masih memproduksi batu tela secara terus menerus pada tiap harinya. Berikut data produksi batu tela yang diproduksi Beton Mas sebelum menggunakan sistem Just In Time :

Tabel 1. Produksi Batu Tela sebelum JIT periode 2018

\begin{tabular}{lc}
\hline Bulan & Total Produksi \\
\hline Januari & 5,550 \\
Februari & 6,500 \\
Maret & 4,350 \\
April & 9,470 \\
Mei & 5,500 \\
Juni & 7,230 \\
Juli & 7,700 \\
Agustus & 12,800 \\
September & 15,500 \\
Oktober & 20,360 \\
November & 16,630 \\
Desember & 10,780 \\
\hline Total & $\mathbf{1 2 2 , 3 7 0}$
\end{tabular}

Dari data pada tabel 1 yang peneliti sajikan di atas bisa dilihat bahwa jumlah produksi batu tela yang harus di produksi Beton Mas pada tahun 2018 sebesar 122,370 batu tela

Berdasarkan hasil analisis yang telah diuraikan, maka diketahui gambaran keadaan sesungguhnya Beton Mas terkait dengan penggunaan sistem tradisional. Untuk mendapatkan produksi batu tela yang efisien pada perusahaan maka perlu mengubah sistem tradisional dengan sistem Just In Time.

\section{Data Persediaan Produk batu Tela Sesudah Penerapan Just In Time}

Penerapan sistem Just In Time Purchasing bahwa perusahaan tidak menyimpan persediaan bahan baku digudang. Perusahaan hanya membeli bahan baku sesuai dengan kebutuhan untuk memproduksi produk atau pesanan. Karena perusahaan menginginkan efisiensi bahan baku yang maksimal yaitu dengan jalan menghilangkan biaya persediaan terutama untuk biaya penyimpanan. Data rata-rata produksi sesuai pesanan batu tela Beton Mas per bulan pada tahun 2018disajikan pada Tabel 2.

Tabel 2. Produksi Batu Tela setelah JIT periode 2018

\begin{tabular}{lcc}
\hline Bulan & Pesanan & Total Produksi \\
\hline Januari & $7 \mathrm{kali}$ & 3,350 \\
Februari & $9 \mathrm{kali}$ & 6,500 \\
Maret & $5 \mathrm{kali}$ & 3,200 \\
April & $10 \mathrm{kali}$ & 8,220 \\
Mei & $6 \mathrm{kali}$ & 4,780 \\
Juni & $11 \mathrm{kali}$ & 7,230 \\
Juli & $5 \mathrm{kali}$ & 4,760 \\
Agustus & $14 \mathrm{kali}$ & 10,880 \\
September & $15 \mathrm{kali}$ & 14,670 \\
Oktober & $18 \mathrm{kali}$ & 18,360 \\
November & $16 \mathrm{kali}$ & 15,380 \\
Desember & $13 \mathrm{kali}$ & 11,980 \\
\hline Total & $\mathbf{1 2 9}$ kali & $\mathbf{1 0 9 , 3 1 0}$ \\
\hline Sumber
\end{tabular}

Sumber : data diolah, 2019

\section{Perbedaan Biaya Penyimpanan Sebelum Dan Sesudah Penerapan Sistem Just In Time Purchasing}

Untuk analisis lebih lanjut kita bandingkan besarnya biaya penyimpanan bahan baku sistem tradisional dengan sistem Just In Time pada Tabel 3.

Hasil perhitungan ini dapat memberikan informasi bahwa jumlah biaya penyimpanan bahan baku antara sebelum penerapan Just In Time Purchasing dan sesudah penerapan Just In Time Purchasing terdapat perbedaan. Produksi 
sebelum penerapan Just In Time Purchasing adalah sebesar 122,370. dan sesudah penerapan Just In Time Purchasing sebesar 109,310. Penerapan sistem Just In Time mampu menekan biaya penyimpanan sebesar 13,060. Dengan menekan produksi berlebihan sebesar 13,060. maka penerapan Just In Time Purchasing dapat meningkatkan produktivitas perusahaan.

Tabel 3 Perbandingan Produksi Batu Tela Sistem Tradisional dan Sistem Just In Time

\begin{tabular}{lccc}
\hline & Sistem Tradisional (Rp) & Sistem JIT (Rp) & \multicolumn{1}{c}{ Selisih(Rp) } \\
Batu tela & 122,370 & 109,310 & 13,060
\end{tabular}

Sumber : data diolah, 2019

\section{Sistem Just In Time Production}

\section{Aktivitas Produksi Batu Tela}

Untuk memproduksi campuran batu tela, selain bahan yang digunakan adapun jenis peralatan produksi yang digunakan dalam memproduksi campuran batu tela dapat meliputi: (1). Cangkul, (2). Sekop, (3) Cetakan. Selanjutnya tahap-tahap yang dilakukan dalam memproduksi campuran beton dapat diuraikan seperti pada Tabel 4 .

Tabel 4. Proses Produksi Batu Tela Dan Waktu Yang Diperlukan

\begin{tabular}{clc}
\hline No & \multicolumn{1}{c}{ Kegiatan Produksi } & Waktu Pengerjaan (menit) \\
\hline 1. & Pemeriksaan bahan baku sebelum di pindahkan ke tempat pencampuran & 15 \\
2. & Pemindahan bahan baku dari gudang ke tempat pencampuran & 10 \\
3. & Penimbangan / penakaran bahan baku & 20 \\
4. & Pencampuran bahan baku & 30 \\
5. & Pencetakan & 30 \\
6. & Quality Control & 30 \\
7. Pengetakan hasil di gudang untuk di jual & 30 \\
\hline \multicolumn{2}{l}{ Total }
\end{tabular}

Sumber : Beton Mas

\section{Keseluruhan Waktu yang Diperlukan Dalam}

\section{Proses Produksi Batu Telo}

Penerapan sistem produksi sangatlah diperlukan oleh perusahaan, sebab dengan perhitungan sistem produksi yang akurat maka efektivitas dalam pengelolaan produksi akan terlaksana sesuai dengan yang diharapkan. Salah satu pengukuran yang digunakan oleh perusahaan dalam mengukur keseluruhan waktu yang diperlukan dalam pengolahan bahan baku menjadi produk jadi adalah troughput time. Data throughput time disajikan pada Tabel 5.

Tabel 5. Data Troughput Time Dalam Produksi Batu Tela Pada Usaha Batu Tela Beton Mas

\begin{tabular}{|c|c|c|c|c|c|c|}
\hline \multirow{2}{*}{ No } & \multirow{2}{*}{ Bagian Produksi } & \multirow{2}{*}{$\begin{array}{c}\text { Aktivitas penambahan } \\
\text { nilai (Value added activity) } \\
\text { Processing Time }\end{array}$} & \multicolumn{3}{|c|}{$\begin{array}{l}\text { Aktivitas bukan penambahan } \\
\text { nilai (Non value added activity) }\end{array}$} & \multirow{2}{*}{$\begin{array}{l}\text { Troughput } \\
\text { Time }\end{array}$} \\
\hline & & & $\begin{array}{c}\text { Waiting } \\
\text { Time }\end{array}$ & $\begin{array}{l}\text { Move } \\
\text { Time }\end{array}$ & $\begin{array}{c}\text { Inspection } \\
\text { time }\end{array}$ & \\
\hline 1. & Penimbangan & 20 & 10 & & 15 & 45 \\
\hline 2. & Pencampuran & 30 & 30 & & & 60 \\
\hline 3. & Cuality Control & 30 & & & & 30 \\
\hline 4. & Stacking & 30 & & & & 30 \\
\hline & Total & 110 & 40 & & 15 & 165 \\
\hline
\end{tabular}

Sumber: Beton Mas

Berdasarkan Tabel 5, waktu proses yang diperlukan oleh bagian penimbangan 20 menit, pencampuran sebesar 30 menit, quality control 30 menit dan stacking 30 menit. Secara keseluruhan jumlah trhroughput time yang diperlukan adalah 165 menit 3 jam.

\section{Nilai Manufacturing Cycle Efficiency Sebelum Penerapan JIT Production}

Manufacturing Cycle Efficiency merupakan metode pengukuran fisik dari produktivitas perusahaan. Dimana MCE yang ideal adalah sama dengan 1 atau mendekati angka 1, yang berarti perusahaan dapat menghilangkan waktu dari aktivitas yang tidak bernilai tambah (nonvalue added activities) dan mengoptimalkan waktu dari aktivitas yang bernilai tambah (value added activities).

Dari tabel Data Troughput Time dalam Produksi Campuran batu tela dapat disajikan 
Manufacturing Cycle Efficiency (MCE) yang dapat dilihat melalui persamaan berikut ini :

MCE Bagian Penimbangan $=\frac{20}{165 \text { menit }}=0.121$ menit

MCE Bagian Pencampuran $=\frac{30}{165 \text { menit }}=0.181$ menit

MCE Bagian Quality Control $=\frac{30}{165 \text { menit }}=0.181$ menit

MCE Bagian Stacking/Stok $=\frac{30}{165 \text { menit }}=0.181$ menit

Total Manufacturing cycle efficiency $=0.666$ menit

Berdasarkan hasil perhitungan Manufacturing cycle efficiency dalam produksi campuran beton maka total MCE yang didapat sebesar 0,666 atau sebesar 66,6\% (Penimbangan, Pencampuran, Quality Control, dan Stacking). Dari hasil total Manufacturing cycle efficiency sebesar 66,6\%.

\section{Kegiatan Produksi Dan Waktu Yang Diperlukan Setelah Penerapan JIT Production}

Salah satu upaya yang dilakukan oleh perusahaan untuk menghilangkan non value added activities dalam sistem produksi adalah dengan menerapkan strategi Just In Time (JIT). Dimana Just In Time yang diterapkan pada sistem produksi disebut JIT production (sistem produksi Just In Time) yang merupakan suatu sistem penjadwalan produksi komponen atau produk yang tepat waktu, mutu, dan jumlahnya sesuai dengan yang diperlukan oleh tahap produksi berikutnya. Untuk meningkatkan MCE (Manufacturing Cycle Efficiency) dalam produksi campuran beton maka menurut perusahaan aktivitas non value added dapat dihitung sebagai berikut:

a. Dengan menyediakan gudang bahan baku di lokasi pabrik, dapat menekan terjadinya waktu tunggu yang lama saat penimbangan bahan baku untuk digunakan dalam produksi batu tela.

b. Waktu pemeriksaan bahan baku saat akan dilakukan penimbangan yaitu sebesar 15 menit dihilangkan saja, alasannya karena bahan baku sebelum diterima atau dimasukkan ke dalam gudang sudah dilakukan pemeriksaan bahan baku. Jadi tidak perlu lagi dilakukan pemeriksaan bahan baku.

c. Pencetakan bahan baku dihilangkan saja, dimana bahan baku setelah dilakukan pencampuran akan langsung dicetak dan dijemur.

Tabel 6. Proses produksi batu tela dan waktu yang di perlukan

\begin{tabular}{llc}
\hline No & Kegiatan Produksi & Waktu Pengerjaan (menit) \\
\hline 1. & Pemindahan bahan baku dari gudang ke tempat pencampuran & 10 \\
2. & Penimbangan dan pemeriksaan kualitas bahan baku & 20 \\
3. & Pencampuran bahan baku dan pencetakan & 30 \\
4. & Quality Control & 30 \\
5. & Pengetakan hasil di gudang untuk di jual & 30 \\
\hline & Total & $\mathbf{1 2 0}$
\end{tabular}

Sumber : data diolah, 2019

Berdasarkan tabel 6 yakni proses produksi batu tela dan waktu yang diperlukan dengan penerapan JIT Production, maka jumlah jam tenaga kerja langsung yang digunakan dalam produksi campuran beton per hari 2 jam atau 120 menit.

\section{Keseluruhan Waktu Yang Diperlukan Dalam Proses Produksi Batu Tela Setelah Penerapan JIT Production}

Just In Time Production adalah produksi yang tepat waktu dan jumlah sehingga lini produksi hanya berproduksi sejumlah yang diperlukan oleh tahap berikutnya atau sesuai dengan permintaan pembeli.

Penerapan sistem Just In Time Production (Sistem produksi Just In Time) pada usaha batu tela Beton Mas, bahwa perusahaan dapat mengurangi waktu dan biaya produksi dengan cara: mengurangi atau meniadakan "lead time" (waktu tunggu) produksi (konsep waktu tunggu nol). Pengurangan waktu tunggu memungkinkan perusahaan lebih tanggap terhadap permintaan pembeli dan sekaligus mengurangi perusahaan order pada pemasok.

Salah satu pengukuran yang digunakan oleh perusahaan dalam mengukur keseluruhan waktu yang diperlukan dalam pengolahan bahan baku menjadi produk jadi adalah troughput time. Secara detail, Troughput time dapat dilihat pada Tabel 7. 
Tabel 7. Troughput Time Produksi Batu Tela Beton Mas

\begin{tabular}{|c|c|c|c|c|c|c|}
\hline \multirow{2}{*}{ No } & \multirow{2}{*}{ Bagian Produksi } & \multirow{2}{*}{$\begin{array}{c}\text { Aktivitas } \\
\text { penambahan nilai } \\
\text { (Value added activity) } \\
\text { Processing Time }\end{array}$} & \multicolumn{3}{|c|}{$\begin{array}{l}\text { Aktivitas bukan penambahan nilai } \\
\text { (Non value added activity) }\end{array}$} & \multirow{2}{*}{$\begin{array}{l}\text { Troughput } \\
\text { Time }\end{array}$} \\
\hline & & & $\begin{array}{c}\text { Waiting } \\
\text { Time }\end{array}$ & $\begin{array}{l}\text { Move } \\
\text { Time }\end{array}$ & $\begin{array}{c}\text { Inspection } \\
\text { time }\end{array}$ & \\
\hline 1. & Penimbangan & 20 & 10 & & & 20 \\
\hline 2. & Pencampuran & 30 & & & & 30 \\
\hline 3. & $\begin{array}{l}\text { Pengeringan dan } \\
\text { Quality Control }\end{array}$ & 30 & & & & 30 \\
\hline 4. & Stok & 30 & & & & 30 \\
\hline & Total & 110 & 30 & & & 120 \\
\hline
\end{tabular}

Sumber : data diolah, 2019

Berdasarkan tabel throughput time produksi batu tela sebelum dan setelah dilakukan JIT maka throughput time sebelum JIT sebesar 6 jam dan setelah dilakukan JIT maka throughput time sebesar 2 jam atau 120 .

\section{Nilai Manufacturing Cycle Efficiency setelah penerapan JIT Production}

Manufacturing Cycle Efficiency merupakan metode pengukuran fisik dari produktivitas perusahaan. Dimana MCE yang ideal adalah sama dengan 1 atau mendekati angka 1 , yang berarti perusahaan dapat menghilangkan waktu dari aktivitas yang tidak bernilai tambah (nonvalue added activities) dan mengoptimalkan waktu dari aktivitas yang bernilai tambah (value added activities).(Agustina, dkk., 2007).

Maka besarnya $M C E$ dari masing-masing bagian dapat di hitung sebagai berikut :
MCE Bagian Penimbangan $=\frac{20}{120 \text { menit }}=0.17$ menit

MCE Bagian Pencampuran $=\frac{30}{120 \text { menit }}=0.25$ menit

MCE Bagian Quality Control $=\frac{30}{120 \text { menit }}=0.25$ menit

MCE Bagian Stacking/Stok $=\frac{30}{120 \text { menit }}=0.25$ menit

Total Manufacturing Cycle Efeciency $=0.92$ menit

Dari hasil perhitungan Manufacturing Cycle Efeciency dalam produksi campuran batu tela sebelum dan setelah dilakukan JIT, maka Manufacturing Cycle Efeciency setelah dilakukan JIT 0,92 atau $92 \%$ dan sebelum dilakukan JIT sebesar 0,666 atau sebesar 66,6\%.

Berdasarkan uraian tersebut di atas, maka dapat disajikan perbandingan Manufacturing Cycle Efeciency (MCE) sebelum dan setelah dilakukan JIT yang dapat dilihat pada Tabel 8 .

Tabel 8. Perbandingan Manufacturing Cycle Efficiency Sebelum dan Setelah Penerapan JIT

\begin{tabular}{llccc}
\hline No. & \multicolumn{1}{c}{ Bagian Produksi } & $\begin{array}{c}\text { Sebelum JIT } \\
\text { (menit) }\end{array}$ & $\begin{array}{c}\text { Setelah JIT } \\
\text { (menit) }\end{array}$ & Selisih \\
\hline 1. & Bagian Penimbangan & 0.121 & 0.17 & 0.011 \\
2. & Bagian Pencampuran & 0.181 & 0.25 & 0.069 \\
3. & Bagian Quality Control & 0.181 & 0.25 & 0.069 \\
4. & Stacking & 0.181 & 0.25 & 0.069 \\
\hline \multicolumn{2}{r}{ Total } & 0.666 & 0.92 & 0,218 \\
\hline
\end{tabular}

\section{Sumber : data diolah 2019}

Hasil perhitungan ini dapat memberikan informasi bahwa nilai MCE antara sebelum penerapan Just In Time dan sesudah penerapan Just In Time pada sistem produksi terdapat perbedaan. Nilai MCE sebelum penerapan Just In Time adalah sebesar 0,666 atau sebesar $66.6 \%$ dan sesudah penerapan Just In Time sebesar 0.92 atau 92\%. Selisih nilai MCE antara dua penerapan tersebut sebesar 0.218 atau $21.8 \%$.

Dari selisih diatas artinya, penerapan sistem Just In Time Poduction mampu menekan aktivitas yang tidak menambah nilai (non value added) atau meningkatkan manufacturing cycle efficiency sebesar 0,218 atau 21.8\%. Meningkatnya MCE sebesar $21.8 \%$ sesudah penerapan Just In Time pada sistem produksi disebabkan semakin kecilnya aktivitas yang tidak menambah nilai (non value added). Hal ini disebabkan konsep Just In Time selalu mengontrol dan berusaha untuk menekan atau mengeliminasi terjadinya waktu yang tidak menambah nilai (non value added) tersebut.

Meningkatnya MCE sebesar 0.218 atau 21.8\% dan nilai MCE sesudah penerapan Just In Time sebesar 0,92 atau 92\%. Dimana hasil perhitungan MCE ini hampir mendekati angka 1 
atau $100 \%$ maka sistem Just In Time Production dapat meningkatkan produktivitas perusahaan. Hal ini senada dengan hasil penelitian Saputra, dkk, (2014) dan Agustina, dkk., (2007) bahwa peningkatan produktivitas perusahaan diukur dengan menggunakan model Manufacturing Cycle Efficiency. Model ini merupakan metode pengukuran fisik dari produktivitas perusahaan, dimana MCE yang ideal adalah sama dengan 1 atau mendekati angka 1, yang berarti perusahaan dapat menghilangkan waktu dari aktivitas yang tidak bernilai tambah dan mengoptimalkan waktu dari aktivitas yang bernilai tambah.

\section{KESIMPULAN DAN REKOMENDASI}

\section{Kesimpulan}

Berdasarkan hasil penelitian dan analisis data yang telah dilakukan, maka dapat diambil kesimpulan sebagai berikut:

1. Penerapan Just In Time Purchasing dapat menekan produksi batu tela sebesar 13,060. Penerapan sistem Just In Time (JIT) Purchasing secara langsung dapat memberikan dampak yang besar terhadap efisiensi biaya dan produktivitas. Dengan menekan produksi batu tela sebesar 13,060 maka penerapan Just In Time Purchasing dapat meningkatkan produktivitas pada Beton Mas.

2. Penerapan Just In Production pada sistem produksi perusahaan mampu meminimumkan throughput time yakni aktivitas yang tidak bernilai tambah pada proses produksi campuran beton atau meningkatkan manufacturing cycle efficiency rata-rata 0,218 atau $21.8 \%$. Dengan meningkatnya MCE sebesar 0,218 atau $21.8 \%$ dan nilai MCE setelah penerapan Just In Time Production sebesar 0,92 atau 92\%. Dimana hasil perhitungan MCE ini hampir mendekati angka 1 atau $100 \%$ maka sistem produksi Just In Time (Just In Time Production) dapat meningkatkan produktivitas perusahaan.

\section{Rekomendasi}

Adapun saran yang peneliti ingin sampaikan berdasarkan hasil dari penelitian ini ialah:

1. Beton Mas jika ingin meningkatkan produktivitas perusahaan agar dapat memeroleh keunggulan bersaing. dapat menjadikan sistem Just In Time sebagai alternative yang baik untuk mencapai hal tersebut.

2. Apabila Beton Mas menerapkan sistem pembelian Just In Time (Just In Time Purchasing) perusahaan dapat mengurangi biaya yang tidak bernilai tambah akibat kelebihan biaya penyimpanan bahan baku, dan dapat membeli bahan baku dalam jumlah, mutu, dan waktu yang tepat.

3. Dan dengan menerapkan sistem produksi Just In Time (Just In Time Production) karena mampu meminimumkan throughput time yakni aktivitas yang tidak bernilai tambah. Dalam jangka panjang, semakin lama perusahaan akan merasakan manfaatnya oleh perbaikan secara terusmenerus yang dihasilkan oleh sistem tersebut.

4. Bagi penelitian selanjutnya diharapkan dapat menggunakan jenis metode pengendalian persediaan lain seperti: metode MRP (Material Requiremen Planning), EOQ (Economic Order Quantity) atau metode pengendalian persediaan lainnya sehingga dapat dijadikan sebagai perbandingan metode mana yang lebih efektif untuk digunakan dalam mengendalikan persediaan bahan baku.

\section{DAFTAR PUSTAKA}

Adiko. 2010. Penerapan Sistem Pembelian Just In Time Untuk Meningkatkan Efisiensi dan Produktivitas Perusahaan Manufaktur. Jurnal Ilmu \& Riset Akuntansi, Vol. 3 No. 10.

Agustina, Y., Dewi, S., dan Ermadiani, 2007, Analisa Penerapan Sistem Just In Time untuk Meningkatkan Efisiensi dan Produktivitas pada Perusahaan Industri, Jurnal Akuntansi dan Keuangan, Vol. 12, No. 1, Januari: 132146

Diaz, A.P dan Retnani , E.D. 2015. Penerapan Metode JIT Pembelian Bahan Baku dalam Meningkatkan Efisiensi Biaya Bahan Baku. Jurnal Ilmu \& Riset Akuntansi, Vol. 4 No. 10

Emzir. 2014. Metodologi Penelitian Kualitatif: Analisis Data, Edisi 1, Cetakan ke-empat, Penerbit: PT. Rajagrafindo Persada: Jakarta 
Handoko, T. Hani. 2016. Dasar - dasar Manajemen Produksi dan Operasi. Yogyakarta: BPFE - Yogyakarta

Heizer, J., dan Render, B. 2005. Operations Management. Jakarta: Salemba Empat

Hensen, Don R. dan Maryana M. Mowen. 2001. Akuntansi Manajemen. Edisi 7. Buku Satu. Jakarta: Salemba Empat

Meylianti S, Brigita dan Mulia, Fernando. 2009. Pengaruh Penerapan Jit (Just In Time) dan Tqm (Total Quality Management) Terhadap Delivery Performance Pada Industri Otomotif di Indonesia, Jurnal Manajemen Teori dan Terapan, Tahun 2, No.2, Agustus.

Ningrum, Setyo E. 2010. Analisis Implementasi Just In Time Terhadap Peningkatan Produktivitas Perusahaan "X" (Studi Kasus Pada Perusahaan Di Kabupaten SidoarjoJawa Timur). Skripsi tidak dipublikasikan, Jawa Timur: Universitas Pembangunan Nasional "Veteran
Putra, Christyandhika dan Idayati, Farida. 2014. Penerapan Metode Just In Time Untuk Meningkatkan Efisiensi Biaya Persedian Bahan Baku, Jurnal Ilmu \& Riset Akuntansi, Vol. 3 No.1.

Saputra, Muhardi dan Sofiah. 2015. Analisis Implementasi Just In Time (JIT) terhadap Peningkatan Produktivitas Perusahaan pada PT. Ras Jaya (Studi Kasus pada Perusahaan Manufaktur di Cimahi Jawa Barat). Prosiding Manajemen

Schroeder, Roger G. 1994. Manajemen Operasi: Pengambilan Keputusan Dalam Fungsi Operasi . Jilid 2. Edisi 3. Jakarata: Salemba Empat

Tjiptono, Fandy \& Anastasia Diana. 2003. Total Quality Management, Yogyakarta

Yusuf, Muri.2015. Metode Penelitian: Kuantitatif, Kualitatif dan Penelitian Gabungan, Edisi Pertama, Cetakan ke-2, Penerbit: PT. Prenadamedia Group. 